\title{
Fatty acid composition and conjugated linoleic acid content of cheeses produced with goat milk
}

\author{
Keçi sütünden üretilen peynirlerin yağ asidi bileşimi ve konjuge linoleik \\ asit içerikleri
}

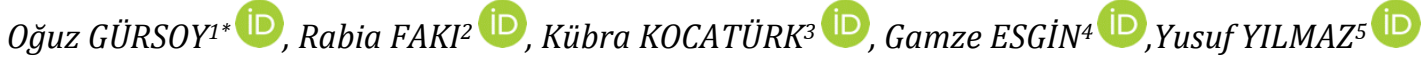 \\ 1-5Department of Food Engineering, Faculty of Engineering and Architecture, Burdur Mehmet Akif Ersoy Univ. Burdur, Turkey. \\ ogursoy@mehmetakif.edu.tr, fakirabia10@gmail.com, kubraakocaturk@gmail.com,gmzesgin@gmail.com, yilmaz4yusuf@yahoo.com
}

\begin{abstract}
In this study, approximate compositions, fatty acid (FA) composition and conjugated linoleic acid (CLA) content of commercial cheeses $(n=13)$ produced predominantly with goat milk in Turkey were determined. FA compositions of cheeses were similar. Major short and medium chain FAs in cheese samples included butyric, caproic and caprylic acids, respectively, according to their relative presence rates. Palmitic, oleic, myristic, stearic, lauric, linoleic and palmitoleic acids were found as the major long chain FAs in all cheese samples while palmitic, myristic and stearic acids were the major saturated FAs in a decreasing order. Palmitic acid was the major FA in cheeses while oleic acid was the dominant unsaturated $F A$. The ratio of lauric to capric acid was lower than 0.78 in all cheese samples. The range for the total CLA contents of cheese samples was from 1.79 to $4.83 \mathrm{mg} / \mathrm{g}$ fat. The highest CLA content was determined in a white cheese sample produced by a mixture of goat (70\%) and cow (30\%) milk while the lowest value was detected in an Ezine cheese sample produced by a mixture of goat (50\%), sheep (45\%) and cow (5\%) milk. Especially, two white cheeses with a high CLA content could significantly contribute to the daily CLA intake of consumers. Results indicated that commercial cheese samples produced in Turkey had a high variability in their CLA contents.
\end{abstract}

Keywords: Goat milk, Cheese, Conjugated linoleic acid, Health, Fatty acid composition.

\section{Introduction}

Goat cheese has been produced and consumed traditionally in Mediterranean countries like Turkey although its relative amount is usually lower than cow or sheep milk cheeses [1]. Interest in goat milk and its products have scientifically and commercially increased over the last three decades steadily because of their potential health benefits [2]. Significant nutritional and beneficial health effects of the consumption of goat milk and its products have been shown in a number of studies along with some epidemiological ones. Prominent nutritional and health benefits of goat milk consumption in comparison to cow milk include;

\section{i. $\quad$ Less allergenic effect [3],[4],}

ii. Better digestibility of milk fat because of low globule size and high short- and medium-chain FA contents [4],
Öz

Bu çalıșmada, ülkemizde ağırlıklı olarak keçi sütü ile üretilen peynirlerin ( $n=13)$ genel kompozisyonu, yağ asidi bileșimi ile konjuge linoleik asit (KLA) içeriği belirlenmiștir. Sonuçlar, tüm peynirlerin yağ asidi bileșimlerinin benzer olduğunu göstermiștir. Farklı peynir örneklerindeki kısa ve orta zincirli yağ asitleri nispi bulunma oranlarına göre bütirik, kaproik ve kaprilik asit olarak sıralanmıștır. Tüm peynir örneklerinde oransal olarak en fazla bulunan uzun zincirli yağ asitleri sırasıyla palmitik, oleik, miristik, stearik, laurik, linoleik ve palmitoleik asit olmuștur. Peynirlerde en fazla bulunan doymus yağ asitleri olarak palmitik, miristik ve stearik asit belirlenmiştir. Peynirlerde, en fazla bulunan yağ asidi ve doymamıs yağ asidinin sırasıyla palmitik asit ve oleik asit olduğu tespit edilmisțtir. Tüm peynir örneklerinde laurik asidin kaprik aside oranı 0.78'den düșük bulunmustur. Peynir örneklerinde toplam KLA içeriğinin 1.79 ile $4.83 \mathrm{mg} / \mathrm{g}$ yağ arasında değiștiği tespit edilmiștir. En yüksek KLA içeriği \%70 keçi sütü ve \%30 inek sütü karıșımından üretilen beyaz peynirde, en düşük KLA içeriği ise \%50 keçi, \%45 koyun ve \%5 inek sütü karıșımından üretilen Ezine peynirinde belirlenmiștir. Özellikle, iki beyaz peynir örneği, tüketicilerin günlük KLA alımına önemli katkı yapma potansiyeline sahiptir. Çalıșma sonuçları, Türkiye'de üretilen ticari peynirlerin KLA içeriklerinde büyük bir değișkenlik olduğunu göstermiștir.

Anahtar kelimeler: Keçi sütü, Peynir, Konjuge linoleik asit, Sağlık, Yağ asidi bileșimi.

iii. Higher contents in mono-and polyunsaturated FAs [4],

iv. Higher contents of essential amino acids including threonine, isoleucine, lysine, cysteine, tyrosine and valine [6],

v. Reduced total and LDL cholesterol levels with goat milk consumption [7], [8],

vi. Improvement of mineral bioavailability [9],[10] and,

vii. Positive effects on human immune system [11].

One of the most significant parameters determining the technological (i.e. texture, color and flavor), nutritional or dietetic quality of milk is its fatty acid composition. Triglycerides are the major constituents of goat milk fat, which corresponds to about $98 \%$ of total lipids [12]. The triglyceride composition of ruminant milk fat is very complicating and can contain up to 1300 different triglycerides [13]. For the fat

${ }^{*}$ Corresponding author/Yazışılan Yazar 
content and FA composition of ruminant milks, the main environmental factor is animal nutrition [5].

Dietary milk fats are associated with some health problems particularly cardiovascular diseases because their saturated FA (SFA) content is high [14]. However, ruminant milk fats have some bioactive components like CLAs [15] and sphingolipids [16]. CLAs are naturally occurring positional and geometric isomers of octadecadienoic (linoleic) acid with conjugated double bounds [17] at various positions (i.e. 9 and 11, 10 and 12,11 and 13) in the carbon chain of FA. Each of the bonds can be in cis or trans configuration [18], [19]. Cis-9, trans-11 (called rumenic acid) and trans-10, cis-12 C18:2 isomers are the most physiologically important isomers and constitute $80-90 \%$ and $3-5 \%$ of total CLAs, respectively. Rumenic acid and trans-10, cis-12 C18:2 isomer are attributed to several beneficial physiological effects such as anticarcinogenic [18], [20], antidiabetic [21], antiatherogenic [22] and antiobesity [23] effects. Dairy products are the major sources for dietary CLAs [17], and they account for about 70\% of total CLA intake [24].

Goat milk has been mainly used for production of white, kashar and Tulum cheeses in Turkish dairy industry. In Turkey, the most produced and consumed cheese is white cheese [25], and it can be a soft (when produced freshly) or semihard (after maturation in brine for 3 months) cheese ripened and stored in brine [26]. Ezine cheese, a white cheese variety, is produced by a mixture of sheep's, goats' and cows' milks in Ezine, a county of the Canakkale city of Turkey. Ezine cheese is produced similarly to white cheese, but the geographical origin of milk used in production contributes a unique characteristic to this cheese [27]. The "Protected Geographical Indication" trademark was assigned to Ezine cheese by the Turkish Patent Institute in 2007. Kashar cheese, a pasta filata type cheese, is the second most important Turkish cheese variety after white cheese [28] and is similar to Kashkaval (Balkans), Caciocavallo (Italy) and Kasseri (Greece) [29]. Kashar cheese, is usually produced with cow and/or sheep milk. However, in recent years, goat milk has been also used in its production. This cheese is either sold fresh or ripened for 3 to 6 months. The production method and some properties of Kashar cheese has been reviewed previously by Kamber [29] in the literature.

Studies on the FA composition and CLA content of goat milk cheeses are limited while most studies are directed towards the FA composition and CLA content of cow milk cheeses. The objective of this study is to determine the approximate and FA composition, and CLA content of different cheeses produced (partially or solely) with goat milk.

\section{Materials and methods}

\subsection{Goat cheese samples}

Goat cheeses were purchased from either local or regional/national markets. Products with a statement of "goat milk" and/or "goat cheese" on their labels were specifically selected. Immediately after cheese samples were purchased, they were transferred into a laboratory refrigerator at $4{ }^{\circ} \mathrm{C}$ prior to analyses. The procedure of the International Dairy Federation (IDF) Standard 50A was followed for sampling from cheeses [30]. The properties of cheese samples and the raw milk type used in their production (according to statements on their labels) are given in Table 1 and label information of cheeses was considered as accurate in interpreting the data. In this study, a total of 13 cheese samples [ 4 white cheeses, a Süzme/Feta type cheese produced with ultrafiltration (UF), 5 Ezine cheeses, a processed (eritme) cheese and 2 Kashar cheeses] were analyzed.

\subsection{Methods}

\subsubsection{Physicochemical analyses}

Total solids content, acidity and salt content of cheese samples were determined by TS 591 [31] while the fat contents of goat milk cheeses were determined by the Gerber method [32]. A digital pH meter (Jenco 6173, Jenco, San Diego, CA, USA) was used to determine the $\mathrm{pH}$ values of cheeses. The crude protein content of cheese samples was assessed by the nitrogen analyzing system DUMATHERM $®$ (Gerhardt, Königswinter, Germany) using the Dumas method [33]. A conversion factor of 6.38 was used to calculate the crude protein contents of cheese samples. The fat and salt contents of cheese samples were also expressed on total solids basis.

\subsubsection{Lipid extraction and preparation of fatty acid methyl esters (FAMEs)}

Lipid extraction from cheeses was performed according to a method proposed by Renner [32]. Grated cheese sample (ca. 20 g) was crushed with kieselguhr (Fluka Chemie GmbH, Buchs, Switzerland) (6-8 g) in a beaker. Diethylether (Fluka Chemie $\mathrm{GmbH}$, Buchs, Switzerland) (200 $\mathrm{mL}$ ) was then added to the mixture and mixed vigorously for a minute. The mixture was filtered and then the solvent was removed from filtered solution (solvent-lipid extracts) at $40^{\circ} \mathrm{C}$ under vacuum by using a rotary evaporator (Scilogex, Rocky Hill, CT, USA). Lipid extract was nitrogen-flushed until dry, and it was stored in a glass vial at $-20^{\circ} \mathrm{C}$ prior to further analyses.

Table 1. Cheese samples used in this present study and their composition of raw milk stated on their labels.

\begin{tabular}{|c|c|c|c|c|}
\hline \multirow{2}{*}{ Sample No } & \multirow{2}{*}{ Cheese Type } & \multicolumn{3}{|c|}{ Raw Milk Ratios Stated on Label (\%) } \\
\hline & & Goat milk & Cow Milk & Sheep milk \\
\hline 1 & White & 60 & 40 & - \\
\hline 2 & Ezine & 50 & $\mathrm{~N}^{* *}$ & $\mathrm{~N}$ \\
\hline 4 & White & 60 & 40 & - \\
\hline 5 & Processed (Eritme) & 60 & 40 & - \\
\hline 6 & White & 95 & 5 & - \\
\hline 7 & Ezine & 80 & 10 & 10 \\
\hline 8 & Ezine & 80 & 10 & 10 \\
\hline 9 & Süzme/Feta Type* & 100 & - & - \\
\hline 10 & White & 70 & 30 & - \\
\hline 11 & Ezine & 50 & 5 & 45 \\
\hline 12 & Kashar, Fresh & 90 & 10 & - \\
\hline 13 & Kashar, Ripened & 90 & 10 & - \\
\hline
\end{tabular}


The method of Yilmazer and Secilmis [34] was used to prepare FAMEs. Briefly, methanolic $\mathrm{HCl}(1 \mathrm{~mL}, 1.5 \mathrm{M})$ was mixed with lipid extract $(200 \mu \mathrm{L})$ and waited for 2 hours at $80^{\circ} \mathrm{C}$. After cooling, $0.5 \mathrm{~mL}$ of water was added, and then $1 \mathrm{~mL}$ of hexane was used to extract FAMEs.

\subsubsection{Gas chromatographic analysis}

The system containing an Agilent 78890A gas chromatography unit (Agilent Technologies, Wilmington, DE, USA) equipped with an Agilent $5975 \mathrm{C}$ quadrupole mass spectrometer detector (MS) was used to analyze fatty acids and CLA in cheese samples. An electron impact ionization mode for MS detector was at 70 $\mathrm{eV}$, and mass range was $30-500 \mathrm{~m} / \mathrm{z}$ in a scan mode for fragment ions. A CP-SIL 88 fused silica capillary column (100 $\mathrm{m} \times 0.25 \mathrm{~mm}$ i.d., $0.2 \mu \mathrm{m}$ film thickness; Chrompack, Middleburg, The Netherlands) was used in FAME analyses. The temperature was set to $240^{\circ} \mathrm{C}$ for the injector and detector, and injection volume was $1 \mu \mathrm{L}$. Carrier gas was helium with a flow rate of $1 \mathrm{~mL} / \mathrm{min}$. The temperature program of a column oven was $60^{\circ} \mathrm{C}$ for $4 \mathrm{~min}, 60$ to $175^{\circ} \mathrm{C}$ at $13^{\circ} \mathrm{C} / \mathrm{min}$ for $27 \mathrm{~min}, 175$ to $215^{\circ} \mathrm{C}$ at $4^{\circ} \mathrm{C} / \mathrm{min}$ for $5 \mathrm{~min}$, and 215 to $240^{\circ} \mathrm{C}$ at $4^{\circ} \mathrm{C} / \mathrm{min}$ for $15 \mathrm{~min}$ while the split ratio was set at 1:20. MSDCHEM software was used for data handling. CLA methyl ester (mixture of the cis- and trans- isomers of 9,11- and 10,12-octadecadienoic acid methyl esters, Prod. No. 05632) and Supelco® 37 Component FAME Mix (Sigma-Aldrich, Cat. No. 47885 U) was purchased from Interlab Inc. (Istanbul, Turkey).

\subsubsection{Statistical analysis}

Triplicates of analyses were expressed as mean \pm standard deviation. Microsoft Excel ${ }^{\circledR}$ software (Washington, USA) was used to perform all calculations.

\section{Results and discussion}

\subsection{Composition of cheese samples}

The composition, $\mathrm{pH}$ and acidity value of cheese samples are shown in Table 2. The total solids contents of cheese samples were between 41.09 (UF white cheese) and 60.98\% (ripened Kashar cheese). Total solids contents of cheese samples studied were higher than a minimum value in cheese groups specified in the Turkish Food Codex (TFC) Cheese Notification (2015/6) [35]. The crude fat content of samples ranged from 22.00 to $29.00 \%$ while the total solids-based fat content (data not shown) varied from $45.92 \%$ (ripened Kashar cheese) to $55.98 \%$ (white cheese). According to the TFC Cheese
Notification, all cheese samples were within a category of fullfat cheeses. This result was also consistent with statements on the label of cheeses. The salt contents of cheese samples were between 2.68 (fresh Kashar cheese) and 5.56\% (Ezine cheese). In general, $\mathrm{pH}$ and acidity values of all cheese samples were in good agreement with literature values [36], [37].

\subsection{Fatty acid composition of goat milk cheeses}

Fatty acid compositions of cheese samples are presented in Table 3. In general, the FA compositions of all cheese types were found similar. Five fatty acids (C16:0, C18:1, C18:0, C14:0, C10:00) were quantitatively accounted for $>78 \%$ of total FAs in all cheeses (Table 3). This result was similar to the value reported $(>75 \%)$ by Alonso et al. [38] for the same FAs in various goat milk samples.

Lipolysis in cheese increases the content of free FAs, and particularly short- and medium-chain FAs contribute to cheese flavor directly [39]. The FAs caproic (C6:0), caprylic (C8:0) and capric acids (C10:0) are usually responsible for the distinctive aroma of goat milk cheeses [1]. Short- and medium-chain FAs in cheese samples were capric, caprylic, caproic and butyric (C4:0) acids. Interestingly, butyric acid content was higher than caproic acid in some cheese samples. Higher ratios of caprylic and capric acids were detected in lipid extracts of Ezine, Süzme/Feta type and white cheese samples (sample numbers of 3, 9 and 10) produced with 80,100 and $70 \%$ goat milk, respectively. Results were in good agreement with Alonso et al. [38], who assumed that dairy products made of goat's milk had a high content of these two FAs (C8:0 and C10:0).

Results indicated that the capric and caproic acid contents of cheeses did not increase linearly with an increase in the ratio of goat milk used in production for different cheese types. This was also noticeable for the same cheese types, which contained the same proportion of goat milk, due to the different production practices in each enterprise. This result might be related with compositional differences of milk used and processing technology in cheese production. Long chain FAs in cheese samples in a decreasing order included palmitic (C16:0), oleic (C18:1 n-9), myristic (C14:0), stearic (C18:0), lauric (C12:0), linoleic (C18:2 n-6) and palmitoleic (C16:1 n-7) acids. In some cheese samples, e.g. white (sample numbers 1 and 10), Süzme/Feta type (sample number 9), Ezine (sample numbers 2, 3, 8 and 11), processed (sample number 5), stearic acid was found more abundant than myristic acid.

Table 2. Chemical properties of cheese samples used in this study (mean \pm standard deviation).

\begin{tabular}{|c|c|c|c|c|c|c|}
\hline Sample & Total Solids (\%) & Fat $(\%)$ & Protein (\%) & Salt (\%) & $\mathrm{pH}$ & Acidity (\%) \\
\hline 1 & $51.81 \pm 0.13$ & $29.00 \pm 0.00$ & $19.65 \pm 0.51$ & $3.02 \pm 0.08$ & $4.78 \pm 0.01$ & $2.47 \pm 0.01$ \\
\hline 2 & $46.76 \pm 0.14$ & $23.25 \pm 0.35$ & $18.68 \pm 0.21$ & $3.82 \pm 0.09$ & $4.94 \pm 0.02$ & $1.79 \pm 0.02$ \\
\hline 3 & $49.28 \pm 0.27$ & $26.50 \pm 0.71$ & $17.73 \pm 0.13$ & $4.05 \pm 0.09$ & $4.88 \pm 0.01$ & $1.91 \pm 0.01$ \\
\hline 4 & $50.05 \pm 0.10$ & $25.00 \pm 0.00$ & $20.25 \pm 0.28$ & $4.03 \pm 0.00$ & $5.14 \pm 0.01$ & $1.89 \pm 0.08$ \\
\hline 5 & $50.03 \pm 0.28$ & $25.00 \pm 0.71$ & $16.64 \pm 0.20$ & $3.16 \pm 0.01$ & $5.02 \pm 0.01$ & $2.11 \pm 0.12$ \\
\hline 6 & $51.02 \pm 0.30$ & $25.75 \pm 0.35$ & $19.29 \pm 0.13$ & $4.92 \pm 0.02$ & $5.16 \pm 0.01$ & $1.66 \pm 0.00$ \\
\hline 7 & $48.17 \pm 0.19$ & $24.00 \pm 0.71$ & $18.24 \pm 0.17$ & $5.56 \pm 0.04$ & $4.74 \pm 0.00$ & $1.92 \pm 0.06$ \\
\hline 8 & $48.09 \pm 0.08$ & $23.00 \pm 0.00$ & $17.80 \pm 0.24$ & $4.80 \pm 0.02$ & $4.98 \pm 0.01$ & $1.97 \pm 0.00$ \\
\hline 9 & $41.09 \pm 0.07$ & $22.00 \pm 1.41$ & $12.70 \pm 0.12$ & $2.71 \pm 0.09$ & $4.57 \pm 0.01$ & $2.12 \pm 0.00$ \\
\hline 10 & $48.56 \pm 0.26$ & $26.25 \pm 0.35$ & $17.64 \pm 0.14$ & $4.74 \pm 0.09$ & $4.90 \pm 0.00$ & $1.84 \pm 0.11$ \\
\hline 11 & $49.01 \pm 0.01$ & $26.75 \pm 0.35$ & $18.65 \pm 0.09$ & $3.98 \pm 0.06$ & $5.02 \pm 0.01$ & $1.93 \pm 0.06$ \\
\hline 12 & $55.05 \pm 0.06$ & $27.50 \pm 0.71$ & $23.77 \pm 0.46$ & $2.68 \pm 0.10$ & $5.24 \pm 0.01$ & $1.52 \pm 0.09$ \\
\hline 13 & $60.98 \pm 0.14$ & $28.00 \pm 0.00$ & $26.94 \pm 0.13$ & $4.44 \pm 0.05$ & $5.80 \pm 0.01$ & $1.36 \pm 0.41$ \\
\hline
\end{tabular}


Table 3. Composition of fatty acids (\%) in extracted lipids of goat cheese samples (mean \pm standard deviation).

\begin{tabular}{|c|c|c|c|c|c|c|c|}
\hline \multirow{2}{*}{ Fatty Acid } & \multicolumn{7}{|c|}{ Cheese Samples } \\
\hline & 1 & 2 & 3 & 4 & 5 & 6 & 7 \\
\hline $\mathrm{C} 4: 0$ & $1.05 \pm 0.08$ & $1.00 \pm 0.01$ & $1.04 \pm 0.06$ & $0.99 \pm 0.01$ & $0.98 \pm 0.00$ & $0.80 \pm 0.02$ & $0.92 \pm 0.01$ \\
\hline C6:0 & $1.22 \pm 0.00$ & $0.92 \pm 0.01$ & $1.17 \pm 0.00$ & $0.97 \pm 0.01$ & $1.25 \pm 0.01$ & $1.02 \pm 0.01$ & $1.08 \pm 0.02$ \\
\hline C7:0 & $0.02 \pm 0.00$ & $0.01 \pm 0.00$ & $0.01 \pm 0.00$ & $0.01 \pm 0.00$ & $0.01 \pm 0.01$ & $0.01 \pm 0.01$ & $0.01 \pm 0.00$ \\
\hline $\mathrm{C} 8: 0$ & $1.95 \pm 0.00$ & $0.92 \pm 0.01$ & $1.98 \pm 0.01$ & $1.27 \pm 0.02$ & $1.93 \pm 0.01$ & $1.40 \pm 0.02$ & $1.82 \pm 0.04$ \\
\hline $\mathrm{C} 9: 0$ & $0.04 \pm 0.00$ & $0.02 \pm 0.00$ & $0.01 \pm 0.00$ & $0.02 \pm 0.00$ & $0.04 \pm 0.00$ & $0.03 \pm 0.00$ & $0.04 \pm 0.00$ \\
\hline C10:0 & $6.69 \pm 0.04$ & $6.40 \pm 0.04$ & $7.15 \pm 0.07$ & $4.11 \pm 0.03$ & $6.46 \pm 0.03$ & $4.69 \pm 0.04$ & $6.05 \pm 0.10$ \\
\hline C11:0 & $0.20 \pm 0.00$ & $0.17 \pm 0.09$ & $0.21 \pm 0.02$ & $0.29 \pm 0.01$ & $0.25 \pm 0.01$ & $0.27 \pm 0.00$ & $0.25 \pm 0.01$ \\
\hline $\mathrm{C} 14: 0$ & $9.92 \pm 0.08$ & $9.69 \pm 0.26$ & $9.20 \pm 0.03$ & $10.19 \pm 0.07$ & $9.42 \pm 0.09$ & $9.45 \pm 0.13$ & $10.21 \pm 0.20$ \\
\hline C14:1n-5 & $0.47 \pm 0.01$ & $0.86 \pm 0.01$ & $0.16 \pm 0.00$ & $1.00 \pm 0.01$ & $0.59 \pm 0.15$ & $0.86 \pm 0.02$ & $0.46 \pm 0.02$ \\
\hline C15:0 & $1.07 \pm 0.00$ & $0.95 \pm 0.01$ & $1.03 \pm 0.03$ & $1.04 \pm 0.00$ & $0.90 \pm 0.00$ & $0.95 \pm 0.00$ & $1.19 \pm 0.02$ \\
\hline C15:1n-5 (cis) & $0.26 \pm 0.02$ & $0.25 \pm 0.04$ & $0.21 \pm 0.02$ & $0.07 \pm 0.00$ & $0.04 \pm 0.00$ & $0.14 \pm 0.13$ & $0.23 \pm 0.04$ \\
\hline C16:0 & $29.42 \pm 0.17$ & $29.08 \pm 0.36$ & $29.72 \pm 0.19$ & $29.22 \pm 0.16$ & $29.13 \pm 0.19$ & $29.23 \pm 0.29$ & $31.38 \pm 0.42$ \\
\hline C16:1n-7 & $1.26 \pm 0.10$ & $1.55 \pm 0.13$ & $1.31 \pm 0.02$ & $1.95 \pm 0.03$ & $1.34 \pm 0.01$ & $1.80 \pm 0.13$ & $1.68 \pm 0.01$ \\
\hline C17:0 & $0.42 \pm 0.02$ & $0.48 \pm 0.01$ & $0.54 \pm 0.17$ & $0.45 \pm 0.02$ & $0.60 \pm 0.05$ & $0.54 \pm 0.01$ & $0.61 \pm 0.17$ \\
\hline$C 17: 1 n-7$ & $0.71 \pm 0.00$ & $0.51 \pm 0.00$ & $0.27 \pm 0.03$ & $0.45 \pm 0.01$ & $0.33 \pm 0.09$ & $0.29 \pm 0.08$ & $0.37 \pm 0.09$ \\
\hline C18:1n-9 & $23.64 \pm 0.12$ & $27.20 \pm 0.54$ & $24.59 \pm 0.53$ & $26.46 \pm 0.55$ & $24.53 \pm 0.84$ & $26.58 \pm 0.19$ & $23.80 \pm 0.13$ \\
\hline C18:2n-6 & $1.95 \pm 0.05$ & $3.30 \pm 0.01$ & $2.30 \pm 0.03$ & $3.09 \pm 0.09$ & $2.53 \pm 0.43$ & $3.36 \pm 0.10$ & $2.23 \pm 0.17$ \\
\hline C18:2n-6* & $0.46 \pm 0.01$ & $0.79 \pm 0.05$ & $0.56 \pm 0.01$ & $0.88 \pm 0.13$ & $0.76 \pm 0.20$ & $0.95 \pm 0.10$ & $0.35 \pm 0.04$ \\
\hline C18:3n-3 & $0.77 \pm 0.00$ & $0.80 \pm 0.03$ & $0.73 \pm 0.00$ & $0.94 \pm 0.02$ & $0.74 \pm 0.06$ & $0.47 \pm 0.09$ & $0.68 \pm 0.02$ \\
\hline C18:3n-6 & $0.89 \pm 0.01$ & $0.26 \pm 0.01$ & $0.79 \pm 0.01$ & $0.53 \pm 0.00$ & $0.37 \pm 0.07$ & $0.89 \pm 0.01$ & $0.85 \pm 0.02$ \\
\hline C20:0 & $0.18 \pm 0.00$ & $0.19 \pm 0.01$ & $\mathrm{nd}^{* *}$ & $0.29 \pm 0.02$ & $0.16 \pm 0.00$ & nd & $0.27 \pm 0.09$ \\
\hline Others & $1.56 \pm 0.01$ & $1.10 \pm 0.04$ & $2.49 \pm 0.01$ & $4.08 \pm 0.01$ & $3.32 \pm 0.01$ & $3.89 \pm 0.01$ & $2.45 \pm 0.05$ \\
\hline
\end{tabular}

Table 3. Continued.

\begin{tabular}{|c|c|c|c|c|c|c|}
\hline \multirow{2}{*}{ Fatty Acid } & \multicolumn{6}{|c|}{ Cheese Samples } \\
\hline & 8 & 9 & 10 & 11 & 12 & 13 \\
\hline $\mathrm{C} 4: 0$ & $1.09 \pm 0.13$ & $0.94 \pm 0.06$ & $0.88 \pm 0.00$ & $1.09 \pm 0.16$ & $0.85 \pm 0.01$ & $1.08 \pm 0.14$ \\
\hline C6:0 & $1.02 \pm 0.00$ & $1.45 \pm 0.03$ & $1.15 \pm 0.00$ & $1.13 \pm 0.02$ & $1.12 \pm 0.00$ & $0.93 \pm 0.01$ \\
\hline C8:0 & $1.77 \pm 0.00$ & $2.53 \pm 0.06$ & $1.98 \pm 0.01$ & $1.69 \pm 0.04$ & $1.67 \pm 0.03$ & $1.31 \pm 0.02$ \\
\hline C9:0 & $0.03 \pm 0.00$ & $0.04 \pm 0.00$ & $0.04 \pm 0.00$ & $0.03 \pm 0.01$ & $0.01 \pm 0.00$ & $0.03 \pm 0.01$ \\
\hline C10:0 & $6.05 \pm 0.05$ & $8.80 \pm 0.13$ & $7.04 \pm 0.19$ & $6.25 \pm 0.55$ & $5.50 \pm 0.05$ & $4.50 \pm 0.05$ \\
\hline C11:0 & $0.19 \pm 0.01$ & $0.20 \pm 0.00$ & $0.06 \pm 0.00$ & $0.05 \pm 0.00$ & $0.07 \pm 0.00$ & $0.27 \pm 0.01$ \\
\hline $\mathrm{C} 12: 0$ & $3.02 \pm 0.01$ & $3.81 \pm 0.10$ & $3.69 \pm 0.03$ & $3.53 \pm 0.06$ & $4.18 \pm 0.05$ & $3.20 \pm 0.04$ \\
\hline C14:0 & $9.23 \pm 0.14$ & $9.43 \pm 0.19$ & $9.83 \pm 0.12$ & $9.95 \pm 0.15$ & $10.99 \pm 0.15$ & $10.18 \pm 0.08$ \\
\hline $\mathrm{C} 14: 1 \mathrm{n}-5$ & $0.33 \pm 0.00$ & $0.42 \pm 0.01$ & $0.42 \pm 0.00$ & $0.61 \pm 0.04$ & $0.72 \pm 0.01$ & $0.89 \pm 0.06$ \\
\hline C15:0 & $1.38 \pm 0.35$ & $1.12 \pm 0.02$ & $1.05 \pm 0.01$ & $1.16 \pm 0.02$ & $1.08 \pm 0.01$ & $1.05 \pm 0.01$ \\
\hline C15:1n-5 (cis) & $0.09 \pm 0.00$ & $0.11 \pm 0.00$ & $0.08 \pm 0.01$ & $0.07 \pm 0.02$ & $0.24 \pm 0.02$ & $0.06 \pm 0.00$ \\
\hline C16:0 & $29.31 \pm 0.04$ & $30.46 \pm 0.66$ & $29.17 \pm 0.41$ & $28.37 \pm 0.50$ & $30.02 \pm 0.82$ & $36.26 \pm 0.60$ \\
\hline C16:1n-7 & $1.66 \pm 0.04$ & $1.29 \pm 0.21$ & $2.55 \pm 0.01$ & $1.58 \pm 0.28$ & $1.80 \pm 0.00$ & $2.26 \pm 0.21$ \\
\hline C17:0 & $0.83 \pm 0.01$ & $0.83 \pm 0.01$ & $0.64 \pm 0.05$ & $0.67 \pm 0.02$ & $0.49 \pm 0.01$ & $0.51 \pm 0.05$ \\
\hline $\mathrm{C} 17: 1 \mathrm{n}-7$ & $0.35 \pm 0.04$ & $0.27 \pm 0.02$ & $0.35 \pm 0.01$ & $0.39 \pm 0.01$ & $0.53 \pm 0.09$ & $0.03 \pm 0.08$ \\
\hline C18:1n-9 & $26.97 \pm 0.17$ & $21.06 \pm 0.59$ & $24.72 \pm 0.74$ & $23.52 \pm 0.54$ & $24.22 \pm 0.46$ & $21.80 \pm 0.17$ \\
\hline C18:2n-6 & $2.25 \pm 0.28$ & $1.43 \pm 0.00$ & $2.68 \pm 0.04$ & $3.02 \pm 0.04$ & $3.26 \pm 0.42$ & $1.51 \pm 0.03$ \\
\hline C18:2n-6* & $0.11 \pm 0.12$ & $0.36 \pm 0.01$ & $0.23 \pm 0.01$ & $0.24 \pm 0.04$ & $0.53 \pm 0.02$ & $1.06 \pm 0.17$ \\
\hline C18:3n-3 & $0.77 \pm 0.02$ & $0.64 \pm 0.02$ & $0.72 \pm 0.02$ & $0.82 \pm 0.01$ & $0.26 \pm 0.02$ & $0.53 \pm 0.00$ \\
\hline C18:3n-6 & $1.07 \pm 0.03$ & $1.13 \pm 0.03$ & $0.95 \pm 0.08$ & $1.13 \pm 0.12$ & $0.74 \pm 0.03$ & $0.62 \pm 0.01$ \\
\hline C20:0 & $0.25 \pm 0.03$ & $0.13 \pm 0.08$ & $0.30 \pm 0.11$ & $0.35 \pm 0.10$ & $0.32 \pm 0.10$ & $0.33 \pm 0.05$ \\
\hline Others & $1.27 \pm 0.02$ & $2.12 \pm 0.80$ & $1.21 \pm 0.03$ & $2.65 \pm 0.14$ & 1. $39 \pm 0.01$ & $3.04 \pm 0.03$ \\
\hline
\end{tabular}

Palmitic, myristic and stearic acids were the major saturated FAs in goat cheeses, which was found similar to Pietrzak-Fiećko et al. [40]. The major FA was palmitic acid while the major unsaturated FA was oleic acid in cheeses studied. Similar FA compositions were also found in different cow's milk cheese types [41], and in fresh and semi-hard goat cheeses [5].

Alonso et al. [38] found that the five major FAs in goat's milk were palmitic, oleic, capric, myristic and stearic acids. They reported that the presence of capric and caprylic acids in goat milk was $2.7 \%$ and $9.9 \%$, respectively, and the ratio of lauric (C12:0) to capric (C10:0) acid in goat cheeses was 0.56 while it was 1.14 in cow cheeses. As a characteristic property, the ratio of lauric/capric acids in goat milk is $<0.5$ while it is $>1$ in cow and sheep milk. Thus, the ratio of lauric/capric acids can be used as a significant indicator for the detection of milk falsification [42]. In this present study, the ratio of lauric/capric acids was lower than 0.78 for all cheese samples (Table 4). Lower ratios of lauric/capric acids $(\leq 0.78)$ could be related with a high goat milk ratio $(\geq 50 \%)$ in the production of cheeses. 
Table 4. Conjugated linoleic acid contents of cheeses and the ratio of lauric to capric acids (C12:0/C10:0) in fat samples extracted from cheeses.

\begin{tabular}{|c|c|c|c|c|c|}
\hline $\begin{array}{l}\text { Sample } \\
\text { No }\end{array}$ & Cheese & $\begin{array}{c}\text { Goat milk Ratio Stated on } \\
\text { Label (\%) }\end{array}$ & $\begin{array}{l}\text { CLA content } \\
\text { (mg/g fat) }\end{array}$ & $\begin{array}{c}\text { CLA Content } \\
\text { (mg/100 g of Sample) }\end{array}$ & C12:0/C10:0 \\
\hline 1 & White & 60 & $2.67 \pm 0.07$ & 77.43 & 0.54 \\
\hline 2 & Ezine & 50 & $2.65 \pm 0.06$ & 61.61 & 0.44 \\
\hline 3 & Ezine & 80 & $2.28 \pm 0.02$ & 60.42 & 0.46 \\
\hline 4 & White & 60 & $4.70 \pm 0.09$ & 117.50 & 0.78 \\
\hline 5 & Processed (Eritme) & 60 & $1.91 \pm 0.11$ & 47.75 & 0.56 \\
\hline 6 & White & 95 & $2.17 \pm 0.05$ & 55.88 & 0.68 \\
\hline 7 & Ezine & 80 & $3.65 \pm 0.07$ & 87.60 & 0.57 \\
\hline 9 & Süzme/Feta type* & 100 & $2.10 \pm 0.00$ & 46.20 & 0.43 \\
\hline 10 & White & 70 & $4.83 \pm 0.09$ & 126.79 & 0.52 \\
\hline 11 & Ezine & 50 & $1.79 \pm 0.27$ & 47.88 & 0.56 \\
\hline 12 & Kashar, Fresh & 90 & $3.10 \pm 0.11$ & 85.25 & 0.76 \\
\hline 13 & Kashar, Ripened & 90 & $2.25 \pm 0.00$ & 63.00 & 0.71 \\
\hline
\end{tabular}

\subsection{CLA Contents of cheeses}

The CLA contents of cheese samples ranged from 1.79 to 4.83 $\mathrm{mg} / \mathrm{g}$ fat (Table 4). The highest CLA content was determined in a white cheese (sample number 10) containing a mixture of $70 \%$ goat milk and 30\% cow milk while the lowest was detected in an Ezine cheese (sample number 11) with a mixture of goat (50\%), sheep (45\%) and cow milk (5\%). An increase in goat milk ratio used in cheese production did not result in any increase in the CLA content of cheeses (Table 4).

Prandini et al. [43] reported that goat cheese samples $(n=8)$ contain $4.29 \pm 1.78 \mathrm{mg} / \mathrm{g}$ fat $(1.22 \pm 0.49 \mathrm{mg} / \mathrm{g}$ sample) cis -9 , trans-11 CLA. Eleven cheese samples in this present study had a lower CLA content than those reported by Prandini et al. [43] (Table 4). Cossignani et al. [5] reported that mean CLA contents of fresh and semi-hard goat cheeses produced in Italy were $5.3 \pm 1.5$ and $7.4 \pm 4.9 \mathrm{mg} / \mathrm{g}$ fat, respectively, which were higher than the values of this present study. In general, the CLA content of goat cheese samples in this study was lower than that of cow milk samples reported by Shantha et al. [44], Jiang et al. [45] and Ma et al. [46]. Jahreis et al. [47] reported that sheep and cow milk has higher CLA concentration that goat milk, which could explain the results of this present study.

Several factors such as origin of raw milk, seasonal variations, feeding differences, production and ripening conditions of dairy products may primarily influence the CLA contents of dairy products [48], [49]. Differences in the CLA contents among cheeses in this study could be explained by differences in raw materials used in the production (milk type and ratio, location, season, animal nutrition etc.) and processing and ripening conditions used in the production of different cheese types.

To evaluate the CLA contribution of cheese samples to human diet, the CLA contents were also expressed as mg per $100 \mathrm{~g}$ of product (Table 4). Estimated required daily intake of potential health benefits of CLA was reported as $700-800 \mathrm{mg} /$ day/70 $\mathrm{kg}$ body weight [50], and estimated CLA intake of different populations (except Australia) was stated between 95 (Canada) and $452 \mathrm{mg} /$ day (Germany) [51]. Results indicated that white cheese samples (sample 4 and 10) with the highest CLA contents as $\mathrm{mg} / 100 \mathrm{~g}$ of sample might have a significant potential for the contribution of CLA intake by consumers.

\section{Conclusions}

Results indicated that all cheese types had a similar FA profile. The major short- and medium-chain FAs in all cheese samples were butyric, caproic and caprylic acids. The long chain FAs in all cheese samples in a decreasing order included palmitic, oleic, myristic, stearic, lauric, linoleic and palmitoleic acids. The major saturated FAs in cheeses were palmitic, myristic and stearic acids. The major FA in cheeses was palmitic acid while the major unsaturated FA was oleic acid. The ratio of lauric to capric acids was lower than 0.78 in all cheese samples. The range of the total CLA contents was 1.79 to $4.83 \mathrm{mg} / \mathrm{g}$ fat in cheese samples. Especially two white cheese samples (60 and $70 \%$ goat milk used in the production, respectively) with the CLA contents of 117.50 and $126.79 \mathrm{mg} / 100 \mathrm{~g}$ of sample might significantly contribute to the daily CLA intake for regular consumers.

\section{Acknowledgements}

This study was financially supported by The Scientific and Technological Research Council of Turkey (TUBITAK) under the program of 2209-A.

\section{Author contributions}

Oğuz GÜRSOY supervised the overall experimental design, carried out the literature search, and wrote the manuscript with Yusuf YILMAZ. Rabia FAKI, Kübra KOCATÜRK and Gamze ESGIN collaborated in the collection of cheese samples and performed all chemical analyses. Rabia FAKI, Kübra KOCATÜRK and Yusuf YILMAZ processed the data and performed the statistical analysis. Final manuscript was read and approved by all authors.

\section{Ethics committee approval and conflict of interest}

There is no need to obtain permission from the ethics committee for the article. We declare no conflict of interest.

\section{References}

[1] Poveda JM, Cabezas L. "Free fatty acid composition of regionally-produced Spanish goat cheese and relationship with sensory characteristics". Food Chemistry, 95(2), 307-311, 2006. 
[2] Sepe L, Argüello A. "Recent advances in dairy goat products". Asian-Australasian Journal of Animal Sciences, 32(8), 1306-1320, 2019.

[3] Park YW. "Hypo-allergenic and therapeutic significance of goat milk". Small Ruminant Research, 14(2), 151-159, 1994.

[4] Jirillo F, Magrone T. "Anti-inflammatory and anti-allergic properties of donkey's and goat's milk". Endocrine, Metabolic and Immune Disorders-Drug Targets, 14(1), 27-37, 2014.

[5] Cossignani L, Giua L, Urbani E, Simonetti MS, Blasi F. "Fatty acid composition and CLA content in goat milk and cheese samples from Umbrian market". European Food Research and Technology, 239(6), 905-911, 2014.

[6] Haenlein GFW. "Goat milk in human nutrition". Small Ruminant Research, 51, 155-163, 2004.

[7] Alférez MJM, Barrionuevo M, López-Aliaga I, Sanz-Sampelayo MR, Lisbona F, Campos MS. "The digestive utilization of goat and cow milk fat in malabsorption syndrome". Journal of Dairy Research, 68, 451-461, 2001.

[8] López-Aliaga I, Alférez MJ, Nestares MT, Ros PB, Barrionuevo M, Campos MS. "Goat milk feeding causes an increase in biliary secretion of cholesterol and a decrease in plasma cholesterol levels in rats". Journal of Dairy Science, 88, 1024-1030, 2005.

[9] Alferez M, Lopez-Aliaga I, Nestares T, Diaz-Castro J, Barrionuevo M, Ros P. "Dietary goat milk improves iron bioavailability in rats with induced ferropenic anaemia in comparison with cow milk". International Dairy Journal, 16, 813-821, 2006.

[10] López-Aliaga I, Alférez M, Barrionuevo M, Lisbona F, Campos MS. "Influence of goat and cow milk on the digestive and metabolic utilization of calcium and iron". The Journal of Physiology and Biochemistry, 56, 201-208, 2006.

[11] Xu M, Wei L, Dai Z, Zhang Y, Li Y, Wang J. "Effects of goat milk-based formula on development in weaned rats". Food and Nutrition Research, 59, 28610, 2015.

[12] Kompan D, Komprej A. The effect of Fatty Acids in Goat Milk on Health. Editor: Chaiyabutr N. Milk Production - An Upto-Date Overview of Animal Nutrition, Management and Health, 3-28, IntechOpen, Rijeka, Croatia, 2012.

[13] Vieitez I, Irigaray B, Callejas N, Gonzalez V, Gimenez S, Arechavaleta A, Grompone M, Gambaro A. "Composition of fatty acids and triglycerides in goat cheeses and study of the triglyceride composition of goat milk and cow milk blends". Journal of Food Composition and Analysis, 48, 95-101, 2016.

[14] Shingfield KJ, Chillard Y, Toivonen V, Kaireinus P, Givens DI. Trans Fatty Acids and Bioactive Lipids in Ruminant Milk. Editor: Bösze Z. Bioactive Components of Milk, 3-65, Springer, 2008.

[15] Gürsoy O, Ișık F, Kınık Ö. “Fonksiyonel gıda bileșeni olarak süt ve süt ürünlerinde konjuge linoleik asit (CLA) ve izomerleri". Akademik Gıda, 1(2), 26-32, 2003.

[16] Potočki S. "Potential health benefits of sphingolipids in milk and dairy products". Mljekarstvo, 66(4), 251-261, 2016.

[17] Dhiman TR, Anand GR, Satter LD, Pariza MW. "Conjugated linoleic acid content of milk from cows fed different diets". Journal of Dairy Science, 82, 2146-2156, 1999.
[18] O’Shea M, Lawless F, Stanton C, Devery R. "Conjugated linoleic acid in bovine milk fat: a food based approach to cancer chemoprevention". Trends in Food Science and Technology, 9, 192-196, 1999.

[19] Khanal RC, Dhiman TR. "Biosynthesis of conjugated linoleic acid (CLA): a review". Pakistan Journal of Nutrition, 3(2), 72-81, 2004.

[20] Ip MM, Masco-Welch PA, Ip C. "Prevention of mammary cancer with conjugated linoleic acid: role of the stroma and the epithelium". Journal of Mammary Gland Biology and Neoplasia, 8(1), 103-118, 2003.

[21] Moloney F, Toomey S, Noone E, Nugent A, Allan B, Loscher CE, Roche HM. "Antidiabetic effects of cis-9, trans-11conjugated linoleic acid may be mediated via antiinflammatory effects in white adipose tissue". Diabetes, 56(3), 574-582, 2007.

[22] Mitchell PL, McLeod RS. "Conjugated linoleic acid and atherosclerosis: studies in animal models". Biochemistry and Cell Biology, 86(4), 293-301, 2008.

[23] Wang YW, Jones PJH. "Conjugated linoleic acid and obesity control: efficacy and mechanisms". International Journal of Obesity, 28, 941-955, 2004.

[24] Abd El-Salam MH, El-Shibiny S. "Conjugated linoleic acid and vaccenic acid contents in cheeses: an overview from the literature". Journal of Food Composition and Analysis, 33, 117-126, 2014.

[25] Gursoy 0, Kesenkas H, Yilmaz Y. White Cheese. Editors: Preedy VR, Watson RR, Patel VB. Hand Book of Cheese in Health: Production, Nutrition and Medical Sciences, 183191, The Netherlands, Wageningen Academic Publishers, 2013.

[26] Hayaloglu AA, Guven M, Fox P. "Microbiological, biochemical and technological properties of Turkish White cheese "Beyaz Peynir". International Dairy Journal, 12(8), 635-648, 2002.

[27] Hayaloglu AA, Ozer BH, Fox PF. "Cheeses of Turkey: 2. Varieties ripened under brine". Dairy Science and Technology, 88, 225-244, 2008.

[28] Sert D, Ayar A, Akın A. "The effects of starter culture on chemical composition, microbiological and sensory characteristics of Turkish Kaşar Cheese during ripening". International Journal of Dairy Technology, 60(4), 245-252, 2007.

[29] Kamber U. "The traditional cheeses of Turkey: cheeses common to all regions". Food Reviews International, 24(1), 1-38, 2008.

[30] International Dairy Federation. "Milk and Milk Products: Guide to Sampling Techniques". Brussels, Belgium, IDF Standard 50 A, 1980.

[31] Türk Standartları. "Beyaz Peynir Standardı". Türk Standartları Enstitüsü, Ankara, Türkiye, TS 591. 1995.

[32] Renner E. Milchpraktikum Skriptum zu den Übüngen. Giesen, Germany, Justus Liebig Universitat, 1993.

[33] International Organization for Standardization. "Milk and milk products-Determination of Nitrogen ContentRoutine Method using Combustion according to the Dumas Principle". ISO 14891: 2002, Geneva, Switzerland, 2002.

[34] Yılmazer M, Seçilmiş H. "Bazı serbest yağ asitlerinin metanolik $\mathrm{HCl}$ ortamında türevlendirilmesindeki koşulların incelenmesi". III Ulusal Analitik Kimya Kongresi, Çanakkale, Türkiye, 5-7 Temmuz 2006. 
[35] Türk Gida Kodeksi. "Peynir Tebliği”. Resmi Gazete, 8 Şubat 2015, Sayı: 29261. Ankara, Türkiye, 2015/6, 2015.

[36] Karagul-Yuceer Y, Isleten M, Uysal-Pala C. "Sensory characteristics of Ezine cheese". Journal of Sensory Studies, 22, 49-65, 2007.

[37] Hayaloglu AA. "Volatile composition and proteolysis in traditionally produced mature Kashar cheese". International Journal of Food Science and Technology, 44, 1388-1394, 2009.

[38] Alonso L, Fontecha J, Lozada L, Fraga MJ, Juárez M. “Fatty acid composition of caprine milk: major, branched-chain, and trans fatty acids". Journal of Dairy Science, 82(5), 878-884, 1999.

[39] Collins YF, McSweeney PLH, Wilkinson MG. "Lipolysis and free fatty acid catabolism in cheese: a review of current knowledge. International Dairy Journal, 13(11), 841-866, 2003.

[40] Pietrzak-Fiećko R, Staniewska K, Staniewski B. “Fatty acid profile of milk fat in the local dairy products from northeastern Poland". Polish Journal of Natural Sciences, 32(1), 143-151, 2017.

[41] Kinik 0, Gursoy 0, Seckin AK. "Cholesterol content and fatty acid composition of most consuming Turkish hard and soft cheeses". Czech Journal of Food Sciences, 23, 166-172, 2005.

[42] Djordjevic J, Ledina T, Baltic MZ, Trbovic D, Babic M, Bulajic S. "Fatty acid profile of milk". The 60th International Meat Industry Conference, Mt. Kopaonik, Serbia, 22-25 September 2019.

[43] Prandini A, Sigolo S, Tansini G, Brogna N, Piva G. "Different level of conjugated linoleic acid (CLA) in dairy products from Italy". Journal of Food Composition and Analysis, 20(6), 472-479, 2007.

[44] Shantha NC, Ram LN, O'Leary J, Hicks CL, Decker EA. "Conjugated linoleic acid concentrations in dairy products as affected by processing and storage". Journal of Food Science, 60(4), 695-697, 1995.
[45] Jiang J, Björck L, Fondén R. "Conjugated linoleic acid in Swedish dairy products with special reference to the manufacture of hard cheeses". International Dairy Journal, 7(12), 863-867, 1997.

[46] Ma DWL, Wierzbicki AA, Field CJ, Clandinin MT. "Conjugated linoleic acid in Canadian dairy and beef products". Journal of Agricultural and Food Chemistry, 47(5), 1956-1960, 1999.

[47] Jahreis G, Fritsche J, Möckel P, Schöne F, Möller U, Steinhart H. "The potential anticarcinogenic conjugated linoleic acid, cis-9, trans-11 C18:2, in milk of different species: Cow, goat, ewe, sow, mare, woman". Nutrition Research, 19(10), 1541-1549, 1999.

[48] Seçkin AK, Gursoy O, Kinik 0, Akbulut N. "Conjugated linoleic acid (CLA) concentration, fatty acid composition and cholesterol content of some Turkish dairy products". LWT-Food Science and Technology, 38(8), 909-915, 2005.

[49] Sanz Sampelayo MR, Chilliard Y, Schmidely P, Boza J. "Influence of type of diet on the fat constituents of goat and sheep milk". Small Ruminant Research, 68(1-2), 42-63, 2007.

[50] Watkins BA, Li Y. CLA in Functional Food: Enrichment of Animal Products. Editors: Sebedio JL, Christie WW, Adof RO. Advances in Conjugated Linoleic Acid, Vol. 2, 174-188, Champagin, IL, USA, AOCS Press, 2003.

[51] Van Wijlen RPJ, Colombani PC. "Grass-based ruminant production methods and human bioconversion of vaccenic acid with estimations of maximal dietary intake of conjugated linoleic acids". International Dairy Journal, 20(7), 433-448, 2010. 